\title{
CONCEPTUAL SKILL KEPALA MADRASAH
}

\section{Muhamad Soif}

Balai Diklat Keagamaan Palembang

muhamadsoif@gmail.com

\begin{abstract}
This paper talked about Conceptual Skill of the School (Madrasah) principals participants of education and Training on Strengthening competences of School principals of South Sumatera, Lampung, Bengkulu, and Babel Provinces. This paper is aimed to know how is the conceptual skills of The school principals participants of the education and training on strengthening competences of the school principals. The analysis was emphasized on descriptive theoritic- emphiric, namely comparing among theory related with the facts and described. The conclusions that the participants on strengthening competnces od the school pricipals was having problem with the conceptual skill, this is probably becoming main reason why Madrasah was still left far behind with another public school.
\end{abstract}

Keyword: Conceptual Skills, School principal

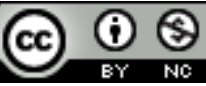

License

This work is licensed under a Creative Commons Attribution-NonCommercial 4.0 International 


\section{PENDAHULUAN}

Kepala Madrasah menurut para ahli, dalam melakukan tugasnya sebagai seorang manajer, harus melengkapi diri dengan Kompetensi Manajerial, yaitu kompetensi yang berhubungan dengan konsep (conceptual Skill), teknik pelaksanaan (technical Skill) dan sosialisasi (social Skill) di antara skill lainnya.

Pemerintah, dalam hal ini Kementerian Pendidikan Nasional mengisyaratkan ada beberapa kompetensi yang harus dimiliki oleh kepala Sekolah yaitu: Kompetensi Kepribadian, Kompetensi Manajerial, Kompetensi Kewirausahaan, dan Kompetensi Supervisi. Sementara itu, Kepala Madrasah, di dalam Peraturan Kementerian Agama, memiliki Tugas 1. Menjalankan tugas manajerial, mengembangkan kewirausahaann dan melakukan supervisi kepada guru dan tenaga kependidikan (PMA, 2017: 4)

Otonomi daerah juga memberikan andil yang sangat besar kepada kepala madrasah, dengan sistem School based-management (MBS/M), Kepala Madrasah menjadi key person karena ia menjadi personal yang paling menentukan kemana madrasah akan berlayar, maju mundurnya madrasah berada di tangan kepala madrasah. Maka dari itu, rekrutmen Kepala Madrasah harus memenuhi beberapa kondisi, 1. Kepala Madrasah yang diangkat mesti berasal dari seorang guru yang berprestasi akademisnonakademis, 2 . berbudi pekerti yang baik, dan 3. memilik pengalaman memimpin madrasah, paling tidak menduduki jabatan sebagai Wakil Kepala Madrasah, 4. Lulus Test (assessment) Kepala Madrasah, dan 5. Mengikuti Diklat Calon Kepala Madrasah, 6. Mengikuti Diklat Penguatan Kompetensi Kepala Madrasah, dan masih banyak lagi Diklat Kepala Madrasah yang lain.

Kondisi di atas diharapkan dapat memenuhi kebutuhan kompetensi Kepala Madrasah dalam melaksanakan tugas manajerialnya, sehingga madrasah berkualitas tinggi menjadi suatu keniscayaan.
Namun hal yang tersebut di atas berbanding terbalik dengan kenyataan di lapangan, usaha-usaha seperti yang didekripsikan seolah-olah tidak secara efektif dan signifikan berimbas kepada kemampuan Kepala Madrasah me-manage madrasah sebagaimana yang diharapkan. Kepala Madrasah belum mampu membuat rencana kerja madrasah yang visioner. Makalah ini, paling tidak, dihadirkan untuk dijadikan solusi mencari jawaban dari permasalahan yang ada.

\section{METODE PENELITIAN}

\section{Rumusan Masalah}

Dari Latar belakang masalah di atas, maka masalah pada penelitian ini dirumuskan sebagai berikut:

Bagaimana Conceptual skill Kepala Madrasah Peserta Diklat Kompetensi Penguatan Kepala Madrasah se-Sumatera Selatan, Lampung, Bengkulu dan Kepulauan Bangka-Belitung?

A. Tujuan Penelitian

Penelitian ini ditujukan untuk menambah pengetahuan dan wawasan, terutama yang berhubungan dengan Conceptual Skills Kepala Madrasah Peserta Pelatihan/Diklat Penguatan Kompetensi Manajerial Kepala Madrasah se-Prov. Sumatera Selatan, Lampung, Bengkulu, dan Bangka-Belitung 2020.

B. Tinjauan Teoritis

Keterampilan konseptual oleh Benton diartikan sebagai kemampuan yang berkaitan dengan menggunakan gagasan dan menjabarkannya untuk mendapatkan pendekatan baru dalam menjalankan departemen-departemen atau perusahaan. Benton menterjemahkan "keterampilan" dengan "kemampuan", sementara itu "konseptual" diterjemahkan dengan "gagasan". Sehingga Benton mengartikan keterampilan konseptual dengan kemampuan menggunakan gagasan. Dari pendapat ini, ada dua kata yang menarik untuk dibahas yaitu gagasan dan menggunakan atau mengaplikasikan gagasan. 
Seorang kepala madrasah (manajer) ada dua hal yang penti ng yang mungkin ada , keduanya atau mungkin satu diantara dua hal penting tersebut, yaitu: gagasan dan kemampuan mengaplikasi gagasan. Punya gagasan adalah satu hal yang positif dan baik untuk kemajuan madrasah, namun akan menjadi suatu yang kurang berarti manakalah tidak ditopang dengan kemampuan (Skills) mengaplikasikan gagasan tersebut menjadi satu tindakan nyata. Hal ini juga sependapat dengan apa yang dikatakan oleh Danim bahwa "keterampilan konseptual adalah kecakapan untuk memformulasikan pikiran, memahami teori-teori, melakukan aplikasi, melihat kecendrungan berdasarkan kemampuan teoritis dan yang dibutuhkan didalam dunia kerja. Kepala madrasah atau para penggelola satuan pendidikan dituntut dapat memahami konsep dan teori yang erat hubungannya dengan pekerjaan.

Dari penjelasan para pakar di atas dapat dismpulkan bahwa kemampuan kepala madrasah dalam memformulasikan pikiran dan gagasan, menentukan strategi, merumuskan kebijakan, serta memutuskan sesuatu yang terjadi di dalam organisasi dapat dilihat dari kemampuannya mengkreasi visi, misi dan tujuan organisasi, meramu strategi, membuat perencanaan dan merumuskan kebijakan. Rasto mengatakan: "Visi, misi dan tujuan organisasi merupakan roh organisasi. Tanpa visi, dan misi organisasi akan berjalan tanpa arah, berputar-putar tidak menuju sasaran dan akhirnya punah. Visi merupakan sebuah daya atau kekuatan untuk melakukan perubahan, yang mendorong terjadinya proses ledakan kreativitas yang dahsyat melalui integrasi dan sinergi berbagai keahlian dari orang-orang yang ada dalam organisasi tersebut.

Dari pendapat di atas, apabila dihubungkan dengan masih rendahnya kualitas output pendidikan dan tidak adanya perubahan kreativitas pada madrasah saat ini, dapat diasumsikan bahwa semua itu merupakan indikator lemahnya conceptual skills Kepala Madrasah, maka dari itu adalah benar dikatakan bahwa Kepala Madrasah merupakan Key person bagi kemajuan madrasah

\section{a. Merumuskan Visi dan Misi}

Tanpa visi yang jelas menurut Rasto organisasi akan berjalan tanpa arah, berputar-putar tidak menuju sasaran dan akhirnya punah. Visi merupakan sebuah daya atau kekuatan untuk melakukan perubahan, yang mendorong terjadinya proses ledakan kreativitas yang dahsyat melalui integrasi maupun sinergi berbagai keahlian dari orang-orang yang ada dalam organisasi tersebut. Bahkan dikatakan Aribowo P. dan Roy S., (2002) bahwa "nothing motivates change more powerfully than a clear vision." Visi yang jelas dapat secara dahsyat mendorong terjadinya perubahan dalam organisasi. Visi inilah yang mendorong sebuah organisasi untuk senantiasa tumbuh dan belajar, serta berkembang dalam mempertahankan survivalnya sehingga bisa bertahan sampai beberapa generasi. Visi tersebut dapat mengikat seluruh anggotanya, juga mampu menjadi sumber inspirasi dalam menjalankan tugas mereka. Oleh karena itu, visi bersama juga berfungsi membangkitkan dan mengarahkan.

Harefa A. (dalam Rasto, 2003:61) menjelaskan visi bukan merupakan sekedar rumusan kata-kata indah yang puitis dan enak didengar. Visi juga bukan sekedar hasil olah pengetahuan (knowledge management), meski ia mencakup hal itu. Visi tidak mungkin diperoleh dari pelatihan (training) sebab pada hakikatnya visi bukan keterampilan. Visi harus berangkat dari hati (heart, perenungan, dan proses pembelajaran), yang kemudian diberi "bingkai" oleh akal budi (ratio, pengetahuan), dan kemudian direalisasikan lewat tindakan nyata (will, keterampilan).

Pradiansyah, A (dalam Rasto, 2003:61) menjelaskan menjalankan visi secara benar 
akan memberikan dampak yang mencerahkan organisasi karena:

1) Visi memberikan sense of direction yang amat diperlukan untuk menghadapi krisis dan berbagai perubahan.

2) Visi memberikan fokus. Fokus merupakan faktor kunci daya saing perusahaan untuk menjadi nomor satu di pasar. Karena focus mengarahkan kita tetap pada bidang keahlian yang kita miliki.

3) Visi memberikan identitas kepada seluruh anggota organisasi. Ini baru terjadi bila setiap individu menerjemahkan visi tersebut menjadi visi dan nilai pribadi mereka.

4) Visi memberikan makna bagi orang yang terlibat di dalamnya. Orang akan menjadi lebih bergairah dan menghayati pekerjaan yang bertujuan jelas.

Dirgantoro C. mengemukakan visi adalah suatu pandangan yang jauh tentang perusahaan, tujuan-tujuan perusahaan dan apa yang harus dilakukan untuk mencapai tujuan tersebut. Suyanto $M$. mengemukakan visi adalah tujuan unik perusahaan yang membedakan perusahaan tersebut dengan perusahaan lain yang sejenis dan mengidentifikasikan cakupan operasinya. Visi merupakan pernyataan atau rumusan umum yang luas dan bersifat tahan lama tentang keinginan atau tujuan perusahaan. Visi ini mengandung filosofis bisnis dari pengambil keputusan strategi perusahaan, menyiratkan citra yang dipancarkan perusahaan, mencerminkan konsep diri perusahaan dan mengidentifikasikan bidang produk (barang, jasa, gagasan) utama perusahaan serta kebutuhan utama pelanggan yang dipenuhi perusahaan. Secara ringkas, visi menguraikan produk, pasar, teknologi yang diterapkan perusahaan, dan ini dilakukan sedemikian sehingga mencerminkan nilai dan prioritas dari pengambilan keputusan stratejik perusahaan. Bateman T.S. dan Snell S.A. (2008:163) menjelaskan visi strategis (strategic vision) mengarah pada masa depan. Visi menyediakan suatu perspektif tentang ke mana arah organisasi itu dan akan menjadi seperti apa. Idealnya pernyataan visi menjelaskan arah jangka panjang organisasi dan maksud strategisnya.

Misi menurut Suyanto M. merupakan operasionalisasi dari visi. Bateman T.S. dan Snell S.A. mengemukakan sebuah misi menjelaskan cara organisasi tersebut beroperasi sekarang ini. Misi (mission) merupakan pernyataan yang jelas dan singkat yang mengandung tujuan dasar organisasi. Misi menjelaskan hal-hal dilakukan oleh suatu organisasi, siapa yang akan dilayaninya, produk atau layanan dasarnya, dan nilainya. Pearce, J.A. dan Robinson R.B. mengemukakan misi adalah tujuan unik yang membedakan suatu perusahaan dengan perusahaan lain yang sejenis dan mengidentifikasikan lingkup operasinya.

b. Merumuskan Sasaran dan Tujuan

Sasaran (goal) menurut Hunger J.D. dan Wheelen T.L., adalah pernyataan terbuka yang berisi satu harapan yang akan diselesaikan tanpa perhitungan apa yang akan dicapai dan tidak ada penjelasan waktu penyelesaiannya. Misalnya sasaran komunitas bank adalah meningkatkan tingkat pengembalian.

Bateman T.S. dan Snell S.A. menjelaskan sasaran berkembang dari pernyataan visi dan misi organisasi. Sasaran-sasaran tersebut tidak akan berarti tanpa dukungan kepemimpinan yang kuat. Suyanto M. mengemukakan sasaran menjelaskan tujuan-tujuan yang spesifik dalam jumlah dan waktu, dengan demikian sasaran memudahkan untuk perencanaan, pelaksanaan dan pengendalian. Dengan kata lain sasaran menunjukkan apa yang ingin dicapai suatu perusahaan. Sasaran perusahaan dapat berupa profitabilitas, posisi pasar, produktivitas, kepemimpinan, teknologi, pengembangan sumber daya 
manusia, hubungan antar karyawan dan tanggungjawab sosial.

Berkaitan dengan tujuan (objective) Hunger J.D. dan Wheelen T.L. menjelaskan tujuan adalah hasil akhir aktivitas perencanaan. Tujuan merumuskan apa yang akan diselesaikan dan kapan akan diselesaikan, dan sebaiknya diukur jika memungkinkan. Pencapaian tujuan perusahaan merupakan hasil dari penyelesaian misi. Komunitas bank sebagai contoh, akan menentukan tujuan dalam satu tahun untuk mendapatkan $10 \%$ tingkat pengembalian dari portofolio investasi.

c. Perencanaan Stratejik

Sekolah merupakan sistem terbuka yang tidak hanya dipengaruhi oleh faktor lingkungan internal, tetapi juga dipengaruhi oleh faktor lingkungan eksternal. Sekolah harus dapat menyesuaikan diri dengan lingkungannya. Perubahan lingkungan yang sangat cepat (turbulence) mengakibatkan tingginya dinamika lingkungan yang selanjutnya menimbulkan ketidakpastian lingkungan yang dihadapi organisasi. Di sinilah pentingnya perencanaan stratejik.

Perencanaan stratejik, mengukur bagaimana madrasah mengadakan pembaharuan menetapkan arah stratejik organisasi yang berorientasi pada kebutuhan para pelanggan baik masa kini, maupun masa yang akan datang. Perencanaan stratejik terdiri atas pengembangan strategi (strategy development) dan penyebaran strategi (strategy deployment).

Pengembangan strategi berkaitan dengan aktivitas yang dilakukan madrasah dalam menentukan strategi organisasi, meliputi aktivitas: (1) merumuskan visi dan misi; (2) menganalisis lingkungan internal untuk mengembangkan strategi; (3) menganalisis lingkungan ekternal untuk mengembangkan strategi; (4) melibatkan guru dalam pengembangan strategi; (5) menetapkan tujuan dan strategi jangka pendek; dan (6) menetapkan tujuan dan strategi jangka panjang.
Rencana strategis dirancang untuk mencapai tujuan organisasi yang lebih luas, yaitu untuk melaksanakan misi yang menjadi satu-satunya alasan kehadiran organisasi tersebut. Perencanaan strategis adalah proses pemilihan tujuan organisasi, penentuan kebijakan dan program yang perlu untuk mencapai sasaran dan tujuan tertentu, serta penetapan metode yang perlu untuk menjamin agar kebijakan dan program strategis itu dilaksanakan, atau secara singkat, perencanaan strategis adalah proses perencanaan jangka panjang yang formal untuk menentukan dan mencapai tujuan organisasi.

d. Perencanaan operasional

Rencana operasional memberikan deskripsi tentang bagaimana rencana strategis dilaksanakan. Rencana operasional terdiri atas rencana sekali pakai dan rencana tetap.

\section{1) Rencana sekali pakai (single use plan)}

Rencana sekali pakai dikembangkan untuk mencapai tujuan tertentu dan ditinggalkan manakala tujuan tersebut telah dicapai. Rencana sekali pakai merupakan arah tindakan yang mungkin tidak akan terulang dalam bentuk yang sama di masa yang akan dating.

\section{2) Rencana tetap (standing plan)}

Rencana tetap merupakan pendekatan yang sudah dilakukan untuk menangani situasi yang terjadi berulang (repetitive) dan dapat diperkirakan. Rencana tetap ini memberikan kesempatan kepada manajer untuk menghemat waktu yang digunakan dalam perencanaan dan pengambilan keputusan karena situasi yang serupa ditangan dengan cara yang konsisten yang telah ditentukan sebelumnya.

Dari deskripsi di atas maka conceptual skill Kepala Madrasah pada penelitian ini diartikan sebagai suatu kemampuan kepala madrasah dalam membuat, merancang dan mengkonsep apa saja (program) yang dikerja untuk memajukan pendidikan madrasah. 


\section{TEMUAN DAN PEMBAHASAN}

\section{Temuan}

\section{a. Visi dan Misi}

Dari data yang ada, sejumlah temuan didapat sebagai berikut :

1) Hampir 100 persen kepala Madrasah perserta Diklat, baik Diklat Substantif Manajemen Berbasis Madrasah, atau Diklat Kerjasama Penguatan Kompetensi Kepala Madrasah dan Pengawasan Madrasah, Akademik, maupun PAI se- Sumatera - Selatan, Lampung, Bengkulu dan kepulauan Bangka Belitung, Diklat Reguler ataupun Diklat di Wilyah Kerja (DDWK), tidak memahami Visi, Misi, Tujuan Pendidikan dan juga tidak memahami bagaimana pembuatan program kerja madrasah.

2) Kepala Madrasah dan Pengawas peserta Diklat dari berbagai angkatan dan jenis Diklat tidak dapat menyebutkan dengan pasti definisi, peranan dan fungsi Visi, Misi dan Tujuan Pendidikan Rencana Program Kerja Madrasah. Ada beberapa perserta Diklat yang dapat memberikan jawaban tentang definisi, peranan dan fungsi Visi, Misi, tujuan Pendidikan dan Program Kerja, tetapi jawabannya tidak cukup memuaskan, jawaban yang diberikan tidak mencerminkan jawaban dari seseorang Kepala Madrasah yang berkompeten di bidang manajemen.

3) Peserta Diklat, dengan alasan lupa, tidak bisa menyebutkan Visi dan Misi Madrasah yang menjadi binaan mereka, apalagi menunjukkan program kerja Madrasah.

4) Visi dan Misi, tujuan Pendidikan dan Program Kerja Madrasah diambil dari hasil googling, copy and paste (dari Internet), tanpa diedit terlebih dahulu.

5) Visi dan Misi Madrasah hanya untuk kelengkapan administrasi saja, dan menjadi persyaratan untuk akreditasi madrasah.

6) Tujuan Pendidikan

Tujuan pendidikan yang merupakan representasi dari Visi Madrsah yaitu Tujuan Pendidikan Jangkah Panjang, setiap madrasah hampir sama, yaitu selalu mengandung variabel "Berakhlak Mulia" kalaupun ada variabel yang berbeda tapi tujuannya sama, seperti "Religius", atau Variabel "Unggul" maupun "prestasi".

7) Rencana Kerja

Rencana Kerja madrasah yang tergambar pada Program Kerja Strategis maupun operasional madrasah, tidak bersinergi dengan Visi dan Misi, sulit untuk dikerjakan, sehingga Visi, Misi dan Tujuan Pendidikan Madrasah mustahil terealisasikan dengan baik,

Sulit untuk membedakan antara program kerja dengan misi, antara Misi dengan Visi, ini menandakan bahwa Kepala Madrasah tidak mengerti apa yang harus mereka kerjakan, Conceptual Sill kepala madrasah tidak cukup bagus untuk memajukan madrasah yang mereka pimpin.

\section{Pembahasan}

Conceptual Skill, yang oleh para ahli diterjemahkan sebagai skill, kemampuan, keterampilan dan kecakapan yang berhubungan dengan pemahaman tentang konsep, ide, gagasan atau teori bagaimana memajukan madrasah tidak nyata terlihat dimiliki oleh para Kepala Madrasah peserta Diklat, baik perserta Diklat Manajemen Berbasis Madrasah (MBM) atau Diklat Kerjasama Penguatan Kompetensi Kepala Madrasah dan Pengawas Madrasah. 
Visi, Misi dan Tujuan Pendidikan serta Program Kerja Madrasah sebagai indikator Conceptual Skill Kepala Madrasah, tidak dipahami oleh Kepala Madrasash, pada hal Program Kerja yang yang menjadi landasan dan sebab Kepala Madrasah bekerja adalah merupakan turunan dari Visi dan Misi Madrasah, yaitu Program Kerja, jikalau Kepala Madrasah tidak memahami Visi dan Misi Madrasah, maka berimplikasi negatif terhadap Program Kerja Madrasah, artinya bahwa Kepala Madrasah bekerja tidak berdasarkan Program Kerja atau tidak berdasarkan pada Kerja yang diprogramkan bersama dengan stakeholder madrasah.

\section{PENUTUP}

\section{Simpulan}

Minimnya pengetahuan Kepala Madrasah tentang peranan penting Visi dan Misi berimplikasi negatif terhadap kemampuan Kepala Madrasah dalam membuat Rencana (Progrm) Kerja Madrasah. Pada hal, Perencanaan sangat menentukan keberhasilan program, karena ia berkaitan dengan: apa (what) yang dikerjakan, siapa (who) yang mengerjakan, bagaimana (how) bekerja kapan (when) dan di mana (Where) dikerjakan dan berapa lama, serta berapa dana yang dibutuhkan dan dari mana sumber dananya. Semua harus terukur dan dievaluasi. Evaluasi adalah alat untuk mengetahui apakah suatu program kerja sudah dikerjakan sesuai dengan rencana dan bagaimana hasilnya, untuk kemudian dapat diambil suatu kebijakan untuk keperluan di masa akan datang.

Minimnya pengetahuan Kepala Madrasah seperti yang dideskripsikan di atas sebagai indikator lemahnya Conceptual skill Kepala Madrasah dalam me-manage Madrasah. Hal ini menandakan bahwa Kepala madrasah sebagai manajer, personal yang paling bertanggung jawab-key person atas maju-mundurnya pendidikan madrasah, tidak memiliki kompetensi konseptual (Conceptual skill), yaitu kompetensi yang berhubungan dengan pemahaman tentang teori-teori, gagasan atau ide-ide bagaimana kiat-kiat, terobosan, strategi yang benar-benar didasarkan pada satu pemikiran yang matang untuk keberlangsungan pendidikan madrasah.

Diklat, sebagai sarana untuk melatih, dan membimbing kepala madrasah tidak berdampak positif dan signifikan karena Mata Diklat yang diberikan, secara substansial, tidak menyentuh akar permasalahan (core of the problem) yang dihadapi oleh para kepala madrasah. Apa yang diberikan kepada Kepala Madrasah bukanlah sesuatu yang benar-benar mereka butuhkan. 


\section{DAFTAR PUSTAKA}

Bateman T.S., Snell S.A.2008. Manajemen, Kepemimpinan dan Kolaborasi dalam Dunia yang Kompetitif. Edisi 7. Buku I. (Jakarta: Salemba Empat. [Online].

Benton, D,A. Applied Human Relations, An Organizational Approach, (New Jersey:Pretice Hall, Englewood Cliffs)

Danim, Sudarwan, 2009, Manajemendan Kepemimpinan Transformasional Kekepalasekolahan, Visi danStrategi sukses Era Teknologi, Situasi Krisis , dan Internasionalisasi Pendidikan, (Jakarta; Rineka Cipta,)

Dirgantoro C. 2007, Manajemen Stratejik. Jakarta: Grasindo. [Online].

Rasto, 2010, Mutu Kinerja Sekolah Menengah Kejuruan, Studi tentang Pengaruh Kompetensi Kepala Sekolah, Manajemen Informasi, Fokus pada Pelanggan, Perencanaan Stratejik, Pengembangan Sumber

Daya Manusia, Kemitraan Sekolah dengan Dunia Usaha dan Dunia

Industri, dan Budaya Mutu terhadap Mutu Kinerja Sekolah

Menengah Kejuruan (SMK) di Kota Cimahi),( DISERTASI, Pascasarjana UPI, Bandung)

Robbins, Stephen P., (2001). Organizational Behavior. (New Jersey: Pearson Education International)

Hunger, J. David, dan Thomas L. Wheelen. 1996, Strategic Management. (Edisi Terjemahan. Yogyakarta: Andi)

Siswanto, H.B, 2005 Pengantar Manajemen, ( Jakarta: Bumi Aksara,)

Suyanto M. 2007, Strategic Management Global Most Admired Companies. (Yogyakarta: Andi Offset) [Online].

Sururi, 2005, Kinerja Kepala Madrasah dalam Meningkatkan Produktivitas Kerja Guru pada Madrasah Tsanawiyah (MTs) se-Kota Cilegon, (Jurnal Administrasi Pendidikan, Vol.III)

Wahyudi, Kepemimpinan Kepala Sekolah Dalam Organisasi Pembelajaran (Learning Organization), Bandung: Alfabeta, 2009), hal. 67

Departemen Pendidikan Nasional Jakarta, Standar Kompetensi Kepala Sekolah TK-SD-SMP-SMA-SLB dengan Pedoman Penilaian Kelas).

Peraturan Menteri Agama 2008 tentang Kepala Madrasah. 